\title{
Violation of Humanitarian Law and Infringement of Human Rights in the Last "Colony" of Africa
}

\author{
HARKAI István ${ }^{1}$
}

\begin{abstract}
On the surface, Western Sahara is one of the most uninteresting regions of Africa, but anyone interested in international law, can easily find many exciting issues to explore. After a brief historical review, the author will try to examine the abuse of human rights and, the infringement of international humanitarian law which were committed by the parties during the fight for freedom of the Sahrawi people. The essay also analyses the circumstances of the refugees.
\end{abstract}

Keywords: Western Sahara, Sahrawis, Polisario, humanitarian law, human rights, status of refugees

\section{Introduction}

The last colony of Africa is one of the most hidden places on Earth, located at the Atlantic coast of the Sahara desert. The area seems to be worthless, but it lies at an intersection of different interests, causing many armed struggles. Despite the sparse population and the inhospitable desert environment, many rich phosphate quarries can be found. The Atlantic coast is strategically important. This was recognized not only by the Spanish colonizers, but the neighboring countries, Morocco, Mauritania and Algeria, as well. Algeria is a supporting actor in the modern history of the region, but Morocco and Mauritania have actively participated in the conflict, following Spanish rule. The two neighbors became occupying powers after the withdrawal of the previous owners, which resulted in armed conflict among the intruders and the Polisario which is fighting for the freedom of the Sahrawi people.

The war in Western Sahara is the root of many of questions based on international law. In this paper I am trying to answer two of them, namely the violation of humanitarian law and the infringement of human rights committed by the parties, and I am also trying to examine the situation of the Sahrawi refugees, who have been forced to leave their homeland.

\section{The History of Sahrawis and the Road to the Conflict}

According to the records of the international community, the disputed area is one of the last areas unable to ensure its own government. [1] The territory of the country is around 266 thousand square kilometers, mostly covered by desert. The number of inhabitants is just over 580 thousand. [2] [3] As is usual in the Maghreb countries, ${ }^{2}$ the indigenous population of Western Sahara belonged to the Berber tribes. These groups of nomad shepherds reached a

1 dr. jur. E-mail: harkai.istvan89@gmail.com

2 The Arabic word means West, it is used as a generic term for the Arabic languaged states - Libya, Tunisia, Algeria, Morocco, Western Sahara and Mauritania - in the Atlas Mountains, Northwest Africa. 
low level of state organization when they created tribeal alliances. [4] The Arabs conquered these lands, and organised the northwest territories of Africa into a new Islamic state, which included almost the whole Iberian Peninsula. Under the rule of the Almoravid and the Almohad Empires, ${ }^{3}$ the Berber tribes transformed their religion into Islam and adopted the Arabic language, as a new dialect, named the Hassanija. [4]

After the Reconquista, strengthening Iberian states, Portugal, Castile and Aragon, made the first expeditions exploring the northwest coast of Africa. Later on the Lusitanian and Spanish sailors established the first colonies on the Isle of Madeira and its archipelago, and on the Canary Islands. From the new possessions the Europeans easily made contact with the people of the Sahara. [5]

Northwest Africa was always poorer than the most visited and exploited Gold, Slave and Pepper Coast along the shores of Gulf of Guinea, so the Europeans started to colonise relatively late. It became a Spanish colony only in 1727, when the king of Spain and the sultan of Morocco, Mohamed ben Abdallah signed a treaty in Marrakesh about the division of the territories and the Sahara zone of interest. [5] The contracting parties not only decided about the division but also established the common goal to take action against pirates threatening the nearby coastal waters, and regulated the rules of fishing. [2] [3] The conditions served the Spanish interest, because the sultan did not have the power to prevent piracy. The pirates barely recognised the authority of the sultan and lived their life according to their own habits and customs. [2] [3]

Other European nations who took part in the colonization of the poorest continent on Earth divided the black continent during the Berlin Conference in 1884. [6] In the Maghreb Region France had almost all of the exclusive rights, so Madrid had to cooperate and negotiate with Paris about the effective rule over Western Sahara and about the borderlines which separated the Spanish and the French sphere of interest from each other. The parties established an agreement on the $27^{\text {th }}$ of June in 1900 , later on they amended this twice, as the result of their negotiations. [5]

After drawing the boarder lines, Spain wanted to extend their authority so far as the boarders were determined. The native people tried to prevent the success of the quick Spanish advance, blocking the path of the invaders. By the year 1938, Spain finally occupied the whole territory of Western Sahara. During this long term the Europeans were cumbered not only by the Sahrawis, but civil war as well. The Iberian troops occupied strategically important settlements, and they controlled the motile tribes by using well equipped patrols continuously. [2] [3] At that time the number of the occupying troops was 13,486. [2] [3]

After the invasion of the country, the Spanish government started to exploit the resources, and fishing in the coastal waters also began. A new city was founded where the seafood processing and packing plants were established. Later on this city, named Laayoune (El Aaiun), became the capital of Western Sahara. [4] The volume of fishing at the beginning of the fifties exceeded 26 thousand tons, which was held in cold storage, and after processing the products were exported. [2] [3] After their discovery, by geologist Manuel A. Medina, phosphate mines were explored and mapped. Phosphate excavation was started in the forties. Because of the high purity, the investors expected a high rate of return. [2] [3] The scientists found not only phosphate, but petroleum as well. While the Spanish government spent a huge amount

3 The Almoravids were a Berber origin dynasty which ruled Maghreb from 1062 to 1147, and were followed by the likewise Berber Almohads. 
of money on the exploitation of the phosphate mines, they did not try to dredge up the oil, because the predictions said that it would be at a fianacial loss. [2] [3]

Not only Spain was interested in the exploitation of the treasure of the soil, but the neighboring countries, which were on the road to independence, as well. Especially Morocco wanted to take over the control of the raw materials in Western Sahara. During the Bandung Conference in 1955, territories under colonial rule and other third countries took a commitment in face of colonialism and imperialism. In the next 20 years many of African countries liberated themselves from colonial rule and joined the group of non-aligned states. Five years later, in 1960, the General Assembly of the United Nations adopted resolution 1514 (XV). That was the Declaration on the Granting of Independence to Colonial Countries and People. ${ }^{4}$ One of the most important principles proclaimed the "necessity of bringing to a speedy and unconditional end colonialism in all its forms and manifestations." [7] The signatories of the treaty declared the right to self-determination, which is also one of the human rights and all the exploitation, subjugation, domination is against this basic principle. [7] This fundamental right was limited immediatelly, because it is in conflict with other elementary terms of international law such as the right to territorial integrity. Right to self-determination could not lead to the harm of border of a sovereign countries, it is forbidden to use as an argument of territorial claims. [8] The right to self-determination is a kind of "one time or disposable" instrument for nations living under the yoke of colonialism. The international community declared twice in two different documents, that "any attempt aimed at the partial or total disruption of the national unity and the territorial integrity of a country is incompatible with the purposes and principles of the international law." ${ }^{5}$ If any nation has taken advantage of this particular right, they are not allowed to "fission" further more, so sovereignty comes before the right to self-determination. [7] There are plenty of such antinomic rules in international relations, which are indicative in the first place of a collision of interests. These colliding rules also prevent and overwrite the prevailing legal norms.

This phenomenon is being observed in the case of Western Sahara. After the liberation of the colonized nations, the Sahrawis also wanted to establish their own state, but their intention was contrary to the interest of neighboring countries, Morocco and Mauritania. The antagonism of the right to self-determination can be explored in the conflict if Western Sahara and Morocco, over and above it has got a special complexion. There is no doubt, that the Sahrawis have got the right to self-determination, and to establish and operate their own state, but the practise of these rights has been delayed, because after the end of Spanish rule, the Moroccan started. As shall be explained further on, the Moroccan invaders look upon the Sahara territory as their own property, and they understate the Sahrawi right to self-determination, interpreting the named right as an anticolonist postulatum. [9] It is clearly understandable, that the emancipated African countries are opposed to any further aspiration for division of their territories. The European colonizing powers drew the boarders in the age of imperialism and did not respect the different ethnic groups. Later on this decision led to serious armed conflicts and civil wars, because the new African powers wanted to prevent further separation.

4 Declaration on the Granting of Independence to Colonial Countries and People (14. 12. 1960)

5 The formulization is almost from the composition of the International Covenant on Civil and Political Rights and the International Covenant on Economic, Social and Cultural Rights. 


\section{From Colony to Occupation - the Root of the Conflict in Western Sahara}

In the sixties, the international community tried to put pressure on Spain to finally permit the referendum where the Sahrawis will decided about their further destiny. The Franco-regime was desparate about the situation in Spanish Sahara, and the main decision-makers secluded themselves from any talk of liberation at that time. Their arguments were firtly the phosphate-mining and fishing. [4] The Spanish dilemma and the emancipation of former African colonies gave hope, flavoured by a measure of nationalism, to the inhabitants of Sahara who created the first organisation in 1967. It was the Movement for the Liberation of Sahara, ${ }^{6}$ which was led by a journalist and Koranic teacher, Mohamed Sidi Ibrahim Bassiri. [10] His profession of faith extended fast, reached not only the provincial population but the citizens as well, who served the Spanish occupants. Those people who served in the Spanish legionary military or as police officers were watched by the Spanish secret services. [2] [3]

The Movement intended to liberate the Sahrawi territories by using peaceful methods and thus organised a demonstration on the $17^{\text {th }}$ of June in 1970 . The demonstration was broken down by the enfilade of the Spanish garrison. [2] [3] At the beginning of the seventies, independence movements found supporters in the neighboring countries. On a rhetorical level Morocco was the first, and sharply protested against the Spanish rule, because the Spanish government was unwilling to execute the decolonisation process. The intention behind the attitude of the westernmost Arabic country was aimed at the annexation of Western Sahara, although a scenario for the annexation did not exist at that time. However, on the eve of liberation of Rabat from French rule, a so-called "Greater-Morocco" concept had already been created, which was worked out by the politician Allal el-Fassi, who was also the first hierophant of this theory. According to this the borders of one-time Almoravid Empire had to be restored, including the Sahrawi lands. [10] In 1965 the uncle of the Moroccan king, Moulay Hassan Ben Driss founded a party struggling for the liberation of Spanish Sahara, with the assignment of initiating and lobbying, to facilitate the holding of a referendum. [10]

In Morocco the expected referendum was looked on with optimism. The king and the government believed that after they secede from Spain the Sahrawis will decide to join Morocco immediately. However Spain did not want to release Western Sahara which is rich in raw materials. They offered extensive autonomy and founded the Party of Sahrawi National Unity, where delegates got a seat in the national assembly, the Jemma. The Party drew a political programme, which contained 14 points for a peaceful solution, considered the only way towards liberation. The programme rejected the territorial claims of the neighboring countries and declared the right to self-determination. [10] This point of view was rejected by the Moroccan government to, there is no third way for Sahrawis, they emphasized, either they join the mother-country or they will stay under Spanish rule.

How serious and well grounded was the Moroccan point of view about the right for the Sahrawi territories can be measured from the fact, that King Hassan II applied directly to the International Court of Justice, which gave an answer in the form of a several questions in its advisory opinion. In the first place, in the time of imperialism, Rio de Oro was not "no man's 
land”, namely terra nullius, so Spain was not able to gain possession by occupation. [11] The Final Act of the Berlin Conference in 1884-1885 declared that the state which obtained a seashore region is allowed to extend its domination into the continental areas. [7] The international practise of the $19^{\text {th }}$ century and later on the decision of the International Court of Justice amended this archaic and quite immature legal position, when it declared the fact, that the territory of Western Sahara was not considered terra nullius, because the chieftains and the trunk-alliances ruled the population of the desert as sovereign rulers, representing their own nation in foreign affairs. Afterwards the Spanish invaders entered into relations with these tribes and made them acknowledge Spanish supremacy and "protection”.

In the second place, Rabat wanted to confirm and claim the continuity of "Greater-Morocco”. The government alleged that the predecessors of the kingdom exercised sovereignty over the nomadic tribes they wandered along the frontier of Morocco, Mauritania and Algeria, so they conveyed the Moroccan rule to their descendants.

According to the opinion of the Court, the "alleged immemorial possession of the territory and uninterrupted exercise of authority” was not substantiated. [11] Morocco actually practised some - rather nominal - authority in the past centuries over the tribes wandering permanently, but did not collect taxes, nor organised the administration, nor resisted the adventurous attacks directed at the conquest the Sahara region. [11]

This decision was completely against Moroccan interest, King Hassan II chose a quite special form of intervention. He organised a march to Western Sahara with more than 350 thousand participants. [10] The mass of volunteers - including around 12\% state employees - marching to the south was logistically supported by the ambulance services, police, and secured by the army. [10] The UN called for moderation and tried to persuade the king to cancel or suspend the march, but the international community did not interfere substantively. The march crossed the borders and entered the territory of Spanish Sahara on the $6^{\text {th }}$ of November in 1975, meanwhile the Jemma and the Polisario call upon the Spanish authorities to protect the province from the Moroccan aggression. The garrison was alerted but instead of clashing Spain withdrew during Operation Swallow and evacuated Spanish Sahara. [4]

The Moroccan conquest was facilitated by two important coefficients. One of them was the change in Spanish internal affairs, namely the fall of the Franco-regime and the restoration of the monarchy, the other was the absolute disinterest of the international community. Besides the unapproving statements of the Security Council, the UN did nothing. Besides the unapproving statements of the Security Council, the UN did nothing. Spain admitted, because of the temporary dishevelment of the army, they can not afford a war with Morocco, so they abandoned the colony and accepted the situation and agreed to a compromise with Rabat to protect the Spanish enclaves (Ceuta and Melilla) on the southern shore of the Mediterranean Sea. ${ }^{7}$ In the treaty of Madrid, Spain yielded the province of Sahara, which was divided and occupied by Morocco and Mauritania. That was the beginning of the almost three decades war among the Polisario and the invaders.

In 1975 Spain simply ceeded the former colony, and handed it over to another occupying power. The question is, did Spain have the right to do this, and if not, is Spain responsible for its act in terms of international law? According to the main rule, states are allowed to make an agreement among each other. In these agreements they can even concede territories. Since

7 The Franco-regime was a military dictatorship. After its fall, the army was weakened temporarily. 
Western Sahara did not have the right and possibility of self-government Chapter XI. of the United Nations Charter was applicable to its legal situation. [12] According to Chapter XI. the governing state has the responsibility to ensure the social, economic and political advancement of the ruled colony, and to develop self-government. The Franco-regime scarcely fulfilled these expectations and the treaty of Madrid raises the possibility of invalidity on the ground of jus cogens. According to the Vienna Convention on the law of treaties a norm is considered to be jus cogens if it is unconditionally applicable, derogation is not permitted, and which can be modified only by a subsequent norm of general international law having the same character. [13] These rules are not listed completely, but the international community agrees that - except of a few exceptions - the jus cogens norm is the prohibition of violence, prohibition of genocide, prohibition of slavery and forced labour and the prohibition of piracy. [7] In our case the prohibition of violence emerges. The Spanish government was aware of the Moroccan intention, so Madrid was not allowed to sign the treaty of Madrid validly because the object of the contract was the division of Spanish Sahara, not to mention the fact, that the purpose of the treating parties was the occupation of Western Sahara. Neither Morocco, nor Mauritania wanted to continue the development of self-government in accordance with the Charter of the United Nations.

\section{Basic Terms of Humanitarian Law and the Infringements Committed by the Parties of the Conflict}

Hereinbefore I described the “Green March” as a particular intervention, but can it be conceived of as aggression? Can we consider, on the ground of international law, the war after the "Green March" as armed conflict? To satisfactorily analyze the conflict in Western Sahara, which is still unsolved, we have to clarify some of important terms used for war and warfare, then try to apply them to the case of Polisario and its conflict with the Moroccan and Mauritanian armies.

Foremost we have to explain the terms of violence and aggression invoked in the UN Charter and Resolution 3314. of the General Assembly. Article 2/4 of the Charter says, that states are refrained from the threat or use of force against the territorial integrity or political independence of any state. [7] The terminology of aggression is narrower. Resolution 3314. Article 1 says that aggression is the use of armed forces against the sovereignty, territorial integrity or political independence of another state, or in any other manner inconsistent with the Charter of the UN. [14]

Although the term aggression does not fit directly the case of the "Green March", it definitely can be classified as aggression. Moreover, the covenants on human rights and the Declaration on Principles of International law bear in mind that all nations have the right to develop their own economic, social and political system. In the meantime, all the other states have to abstain from using force against the political independence and territorial integrity of other states. The Moroccan mass movement can fully qualify as an attack against the integrity of Spanish Sahara giving the right of self-defence to the Spanish garrison. Another question is why Spain did not use force in the defence of Spanish Sahara. It is doubtless, that the "Green March" directly led to the Spanish withdrawal.

The termination of aggression is clearly linked to the invasion of Moroccan and Mauritanian armies after the departure of Spanish troops. After clarifying the aggression of neigh- 
boring countries, only one question is left. In the treaty of Madrid, Spain gave up the rule over the province of Spanish Sahara, and seemingly resigned it to the other two parties of the treaty. But the two aggressors entered into an ongoing process. Sahrawis had started to put into practise the principle of self-government, the referendum had already been promised. The illusion of an independent state was wiped out by the invading armies. But who were the targets of the Moroccan and Mauritanian aggression? Hardly Spain, because they hadalready given up and evacuated the province. In my opinion, Morocco and Mauritana were quasi-successors of Spain in the dominion over Western Sahara. Their acts were not only aggressive, but deprived the Saharavi nation of the right to self-government, freedom and independence as well. [7] Therefore the population of Western Sahara still have the right to fight against intruders, because they are still under foreign rule, practically as a colony of Morocco. [7]

In 1973 the Sahrawis established a political-military organisation, the so called Polisaro Front $t^{8}$ which started to fight against the neighboring forces. Originally the Polisario were founded against Spain. They organised and committed some minor crimes, but the real war started after the Spanish withdrawal, when the Sahrawi Arab Democratic Republic was proclaimed on the $27^{\text {th }}$ of February in 1976. [5]

The classic term of war was used for those conflicts which were fought by sovereign states. For these conflicts the international community worked out different rules during history. The two most important of these are The Hague and Geneva law, which are increasingly merging. [15] The so-called law of war and the international humanitarian law consist of a comprehensive regulation regulating what the parties of war are allowed to do on the battlefield, how to treat the hostile soldiers and the civilians. Most of the armed conflicts after World War Two were not clashes among states, they were more like civil wars and other inner conflicts. In these conflict many of other external powers - just like in the case of Western Sahara - got involved usually as a supporting factor on behalf of one of the fighting parties. In our case Morocco is supported and supplied with weapons by France and the United States, the Polisario is supported by Algeria. [4]

The Western Sahara and other similar conflicts have special features. Every confrontation takes place among a regular combatant army and a weaker group of armed people using guerrilla warfare. A combatant (fighter) is someone who is carrying arms openly, commanded by a person responsible for his subordinates, has a fixed distinctive sign recognizable at a distance and conducting their operations in accordance with the laws and customs of war. [16] For the combatant we have to apply additional rights, different from those called civilians by the humanitarian law. Naturally they are also under legal protection, but if they take part in combat, they are going to be militants, consequently they are going to be in necessity of elementary rights, such as the title of prisoner of war. [7] In addition, they will carry individual criminal responsibility for the loss of other life, while a combatant - because this is his duty - shall not be penalized. [17]

If the Moroccan soldiers are combatants, what are the Sahrawi insurgents? The freedom fight is led by the Sahrawi People's liberation army established by the Polisario. Can we presume, that the members of SPLA are combatants, or do we have to apply another terminus for them? When the convention was adopted, the contracting parties agreed that the term could

8 Frente Para la Liberación de Saguia Al Hamra y Rio de Oro - Frente Polisario 
be used for those warriors belonging to resistance movements, if they fill all requirements of the legal category of combatant. The first protocol of the Geneva Convention (III.) amended and extended the term of combatant. After the amendment we have to consider the guerrillas combatants, if they fulfil the requirements named above, even if they are not recognizable. [7]

Although we can apply the term of combatant to the Polisario rebels, the difference is significant between the regular Moroccan army and the armed group of Sahrawi militants. Therefore we have to use the non-state armed group expression. According to the definition of the International Council on Human Rights Policy a non-state armed group is an armed troop, which uses force to achieve their objectives and are not under state control. [18] In my point of view, we can use the definition of non-state armed group for the forces fighting for freedom in Western Sahara, even if the Polisario is functioning as de facto government. On the $27^{\text {th }}$ of February in 1976 Uld Ziou proclaimed the republic in a refugee camp in Algeria. [18] The government of the new state was born in immigration. In these days 78 states have recognized it, including the United Nations in 1978. [2] [3] The UN authorised the Polisario to practise the right to self-determination, even if it has to use force. [4]

If we consider both the Moroccan troops and the Sahrawi People's Liberation Army as belligerents, we have to apply to them all the rights and obligations of the law of war. They are responsible for incidental inhuman treatment, atrocities against the civilians, for the harm to private property and use of illicit arms.

The occupying power also has some responsibilities on hostile territory. According to the advisory opinion of the UN - as I have already referred - Spain did not have the right to transfer its sovereignty over Spanish Sahara to Morocco, but since Rabat did move in, Morocco is practising administrative authority over two-thirds of Western Sahara, even if it is practising it with military support. [19] While administrating Western Sahara, Morocco has to respect all human rights. It is important to notice, the occupying power is not allowed to demand sovereignty over the territory where it is only allowed to practising administrative rights. [19] In the case of Western Sahara, this requirement barely prevails, because Morocco considers Western Sahara as an integral part of the Kingdom.

Regrettably, during the decades of the conflict, many humanitarian crimes were committed and human rights suffered serious harm. Right at the beginning of the conflict, the Moroccan air force struck three refugee camps, later on Rabat deployed napalm. [2] [3] These actions were not only against the Geneva Convention No. IV which declares that the belligerents have to protect the civilians, but also raised further concerns of humanitarian law. The use of napalm is strictly forbidden since 1980. [17] Notwithstanding, it was not prohibited in 1976, but it still put the burden of responsibility on the Moroccan government because of the Geneva law. In war, the written text of law can be easily forgotten. This is the reason, why crimes can occur such as poisoning wells, machinegunning herds, and looting, bullying or public executions. [2] [3] These acts are not only against humanitarian law, but offend human rights as well, and include cases of torture, cruel, inhuman or degrading treatment.

Because the Moroccan army was too big and strong for the Polisario rebels, they turned their force against the weaker foe, Mauritania, which was not able to solve the logistic problems of supplying its troops across the desert. The Sahrawis attacked continuously the Mauritanian units and the mines under Mauritanian rule. The warfare was too expensive for Mauritania which faced a serious economic crisis. Until 1978, when Mauritania got exhausted and the government was upset by a coup, the new leader came to an arrangment with the Polisario 
and drew off the units from Western Sahara. The ceded territory was occupied by Morocco instead of the Polisario Front. [4] The struggle continued, the guerrillas attacked mines efficiently, causing significant losses to the Moroccan army, but they were not able to overcome the much stronger enemy. Morocco placed under its control the biggest municipalities and the mines, but Rabat was not able to defeat the Polisario rebels moving quickly in the desert regions, so in 1980 they decided to build a "wall”. The $2400 \mathrm{~km}$ long fortification was built in order to protect the Moroccan controlled Western Sahara territories from the attack of the Polisario. The standoff held up until 1988, while Morocco committed many violations against the humanitarian law, when settlements were built for thousands of Moroccan citizens in the occupied zone. This fact breaches the obligation of the occupying power, which is not allowed to do any type of colonization in the occupied territory. [7] The parties started negotiations in 1988 trying to find a legal settlement which is acceptable for each party. In 1991 the UN adopted a resolution of arrangement, they created the so-called MINURSO (United Nation Mission for the Referendum in Western Sahara) to organise, transact and control the referendum in Western Sahara. [4] Morocco was unwilling to accept the referendum as a solution, because Rabat was afraid of to lose Western Sahara, if the Sahrawi people vote in favour of the independence. To avoid an undesirable result, the Moroccan government successfully obstructed the referendum. The status of Western Sahara is still unsolved, the referendum is delayed, the international community would prefer a type of settlement where the Sahrawis have a wide scale of autonomy as an integral part of Morocco. This is implicitly unacceptable for the Polisario.

\section{Human Rights and their Status in Western Sahara}

As I have already referred before, violations against humanitarian law and human rights are very common in armed conflicts. As we did in the previous chapter, we have to review the rules of human rights and the regulations that refer to asylum seekers.

Jurisprudence is dividing human rights into three generations. In case of Western Sahara, for the time being, we can to mention only the first generations, which consist of rights that are still in the scope of the Polisario's struggle. The next two generations (economic, social and cultural rights) can only be applied after the ceasation of the conflict.

After World War II the United Nations adopted numerous conventions concerning human rights. These conventions specifying the basic rules and principles of the UN Charter. First in 1948 The Universal Declaration of Human Rights extricated the norms of the UN Charter. [7] From these rules the most important in accordance with our topic is the right to life, the prohibition of torture or cruel, inhuman or degrading treatment, right to independent and impartial judiciary and the right to seek asylum from persecution. [20]

It was a defect of the Declaration in the year 1948 that it did not contain the declaration of the right to self-determination. In 1966 the international community compensated for this in the International Covenant on Civil and Political Rights. [21] Among plenty of other treaties and conventions on human rights we have to emphasize two more. There is the Convention against Torture and Other Cruel, Inhuman or Degrading Treatment or Punishment adopted in 1984, the other is the Geneva Convention Relating to the Status of Refugees adopted in 1951. [7] 
From this short and far from detailed enumeration it is marked out clearly, that Morocco, which considers Western Sahara as its own, harms one of the most essential human right, the right to self-determination. Even if the international community regards the procedure of decolonization as already finished, in my point of view the Sahrawis are still in that state when they are legally allowed to fight against their "colonizers", because they have not succeeded in reaching independence, or its threshold, the referendum. I have also referred to the bombing of refugee camps, which is not only harm against humanitarian law, but also against the right to life, and we could also mention several other mutual abuses against each other's captives.

In the occupied zone, the Moroccan authorities committed dozens of abuses since 1975. It is not a surprise that Morocco did not accomplish the requirements of the "duties of an occupying power”. Fundamental social and economic rights are not granted, according to the estimates, at least 1,500 people have disappeared and have gone missing since the beginning of the conflict, these are those who probably criticized the regime. This fact immediately raises the question of the situation of right to personal security or the freedom of speech or expression. [22] The Moroccan authorities did not respect the rights related to foreign citizens, when they expelled and deported Spanish missionaries and teachers. [23]

\section{Refugees and their Camps}

If we are talking about the law of refugees - leaving the historical background - first we have to mention the 1951 Geneva Convention on the Status of Refugees. This was the first international document relating to the rights of refugees and defining the term of migrants forced to leave their homeland. According to this, refugees are those who "owing to well-founded fear of being persecuted for reason of race, religion, nationality, membership of a particular social group or political opinion, is outside the country of his nationality and is unable, or owing to such fear is unwilling to avail himself of the protection of that country." [24] Examining the definition, we easily can draw the inference that all the migrants fleeing Western Sahara have to be acknowledged as refugees.

The first migrants left their homes after the "Green March” in 1975 and fled into Algeria, where four refugee camps have been built near the town of Tindouf. In these camps, according to the estimates, more than 160 thousands Sahrawi live. [2] [3] The camps, growing almost into town size, were named after Western Sahara cities, for example El-Aaiun, Smara, Dakhla and Awsard. [25] The inhabintants of the camps treat their temporary homes as a province, calling them with an Arab word wilaya, which might sound familiar to Hungarian ears. ${ }^{9}$ The camps are constructed near watercouses and the constructors tried to build them sufficient distances from each other, to avoid the consequences of airstrikes. The communities of refugees who fled in hope of shelter are led by chosen leaders nominated by Polisraio. [25] In the beginning the refugees lived in tents, but nowadays more and more houses are built of sand-brick. The inmates try to produce food on their own, but they still need the donations of international aid agencies. [25]

The regrettable insufficiency of the Algerian refugee regulations is that it tolerates the presence of Sahrawi refugees on its own territory, but it does not allow them to settle down in

9 During the Turkish wars, the occupied zones of Hungary were organised into the so-called eyalet (in Hungarian vilájet.) 
Algeria. Although this is probably not in the interest of Sahrawis, who are enticed to join the Polisario with the possibility of homecoming. Return has many of difficulties. The migrant government of Sahrawis is operating in immigration itself in a small town, Rabouni, where beside the government, the legislation body, the Red Crescent and the MINURSO can also be found. The Sahrawis try to maintain their own social and health status with medical centers and schools. [25] In spite of the relatively satisfying achievement of the education system, living conditions are quite harsh. Water from the nearby sources is almost undrinkable, so they try to ensure supply by water trucks. In spite of the medical centers, cholera, asthma and other infectious diseases are a frequent "guest”, due to the low level of equipment. [26]

For the habitants living in deplorable circumstances, it would be advisable, if they would be allowed to return back to Western Sahara, but it is prevented by their own organisation, the Polisario. The Moroccan government built houses, but the Front does not allow the refugees to move back, trying to put pressure on the Rabat government. [26]

\section{Summary}

This hidden conflict of Africa is quite a significant topic, but also a difficult one. Important because it reveals a part of the world which is unknown to many of us, and because it consists of a lot of interesting issues to analyze from the field of international law. It is difficult at the same time, because its bibliography is not comparable with other conflicts, such as Palestine. Beyond the raised questions, the examination of the conflict is not mainly concerned with the crimes committed against humanitarian law and human rights, but rather the fact, that the UN, in spite of all the well-meaningness and pursuit, was not able to find an adequate solution in any serious conflicts, because those aspirations have been encumbered by the momentary interest of the world-powers. Although the UN and other international aid agencies have proved, that they have imprescriptible merits in the alleviation of humanitarian disasters.

\section{References}

[1] Non-Self-Governing Territories. www.un.org/en/decolonization/nonselfgovterritories.shtml (downloaded: 0301 2015)

[2] BESENYŐ J.: Western Sahara. Pécs: Publikon Publisher, 2009.

[3] BESENYŐ J.: A nyugat-szaharai válság egy magyar békefenntartó szemével. Pécs: Publikon Kiadó, 2012.

[4] MÉSZÁROS Zs.: A Maghreb palesztinjai - a nyugat-szaharai konfliktus a világpolitikai érdekek árnyékában. 2009. www.grotius.hu/doc/pub/IFXJVR/2009_119_meszaros_zsolt.pdf (downloaded: 0301 2015)

[5] BESENYÖ J.: A nyugat-szaharai spanyol népszámlálás és az ENSZ. Afrika Tanulmányok, II 2 (2008), 18-29.

[6] BESENYŐ J.: Nyugat-Szahara Marokkó és Mauritánia által történt megszállása 1975-ben. Honvédségi Szemle, LXV 2 (2011) 52-57.

[7] KENDE T., NAGY B., SONNEVEND P., VALKI L.: Nemzetközi jog. Budapest: Complex Publisher, 2014.

[8] N. SHAW, M.: Nemzetközi jog. Budapest: Complex Publisher, 2008. 
[9] TIBORI SZABÓ K.: A népek önrendelkezésének belső formája: egyéni szabadság vagy jog a kollektív autonómiához? Romániai Magyar Jogtudományi Közlöny, 1 (2005), 41-46.

[10] BESENYŐ J.: Nyugat-Szaharai konfliktus - az önállósodási küzdelem kezdete, a Nemzetközi Bíróság döntése és a „Zöld menet”. Kül-Világ, VI 2 (2009), 37-57.

[11] Western Sahara - Advisory Opinion of 16 October 1975. www.icj-cij.org/docket/ files/61/6197.pdf (downloaded: 0106 2015)

[12] Charter of the United Nations, Chapter XI, Article 73-74.

[13] Vienna Convention on the law of treaties 1969, Article 53.

[14] Definition of Aggression, United Nations General Assembly Resolution 3314 (XXIX). Article 1.

[15] 1949. Geneva conventions; for the Amelioration of the Condition of the Wounded and Sick in Armed Forces in the Field (I.), for the Amelioration of the Condition of Wounded, Sick and Shipwrecked Members of Armed Forces at Sea (II.), for the Treatment of Prisoners of War (III.), and for Protection of Civilian Persons in Time of War (IV.)

[16] Convention (III) relative to the Treatment of Prisoners of War, 1949. Article 4.

[17] KOVÁCS P.: Nemzetközi közjog. Budapest: Osiris Publisher, 2011.

[18] BUCKLEY, O. M.: Unregulated Armed Conflict: Non-State Armed Groups. International Humanitarian Law, and Violence in Western Sahara, 373 (2012), 794-844.

[19] CHINKIN, C.: Laws of occupation. 2009. http://removethewall.org/wp-content/ uploads/2014/05/Laws-of-Occupation-Christine-Chinkin-2009.pdf (downloaded: 0801 2015)

[20] The Universal Declaration of Human Rights, 1948. Article 3., 5., 6., 10., 14.

[21] International Covenant on Civil and Political Rights, 1966. Article 1.

[22] Bureau of Democracy, Human Rights, and Labor. Country Reports on human rights practises. 2302 2001. www.state.gov/j/drl/rls/hrrpt/2000/nea/804.htm (downloaded: 1001 2015)

[23] BBC: Morocco expels five missionaries. BBC News, 30032009 http://news.bbc.co.uk/2/hi/ africa/7971491.stm (downloaded: 1001 2015)

[24] Convention Relating to the Status of Refugess, Geneva, 1951. Article 1.

[25] BESENYŐ J.: A nyugat-szaharai menekültkérdés és az algériai menekülttáborok. Afrika Tanulmányok, 2010. IV 3 (2010), 74-85.

[26] BESENYŐ J.: Nyugat-Szahara és a migráció. Afrika Tanulmányok, V 3 (2011), 34-45. 